\title{
L'invisibile rivelato. Disamina e progetto per un itinerario museale diffuso dell'antica Contea di Mascali
}

\author{
Claudio Patanè \\ Dario Calderone
}

\section{Abstract}

II contributo presenta, una ricerca ed un progetto di 'rigener-azione del patrimonio culturale' di uno specifico ambito geografico, corrispondente al tratto di costa che si affaccia sul Mar lonio e si radica alle pendici dell'Etna, in Sicilia. Questo "paesaggio terracqueo" è stato in passato contrassegnato puntualmente da architetture verticali, le torri d'awistamento costiere, presenti in tutto il Mediterraneo. Artefatti che, come 'macchine del tempo', permettono ancora oggi, di viaggiare immobili per contemplare quell'orizzonte fatto di cielo e di mare, che a noi contemporanei ormai è fin troppo conosciuto, ma in cui regna ancora quell' altrove proteso verso un desiderio, che unisce il presente, la memoria ed il prossimo futuro. Tra queste le Torri d'Archirafi e di Laviefuille sono due architetture militari non più esistenti, 'invisibili', che sorgevano nel litorale di Riposto in provincia di Catania, appartenenti ad un sistema fortificato molto più esteso, a difesa della Contea di Mascali. Lo studio di questi manufatti, le analisi, la disamina di testi, le cartografie storiche, le mappe, i disegni del passato, il loro ridisegno critico analogico, la restituzione e modellazione tridimensionale, hanno portato gli autori a sviluppare un programma strategico di rigenerazione del 'patrimonio culturale invisibile' di questa porzione di paesaggio terracqueo. Sviluppando degli inediti scenari ed itinerari tra il reale e il virtuale, la rappresentazione analogica e digitale, con l'obiettivo di fornire agli enti e amministratori, che gestiscono il patrimonio locale, dei progetti pilota per far riemergere in superficie e ri-connettere l'abitante contemporaneo ormai distratto, a quei luoghi latenti e invisibili che popolano, seppur inconsciamente, la sua memoria.

Parole chiave

heritage, disegno analogico, disegno digitale, invisibile, torri di guardia. relazioni visive con il paesaggio terraqueo circostante Acquerello inchiostro su carnet voyage.

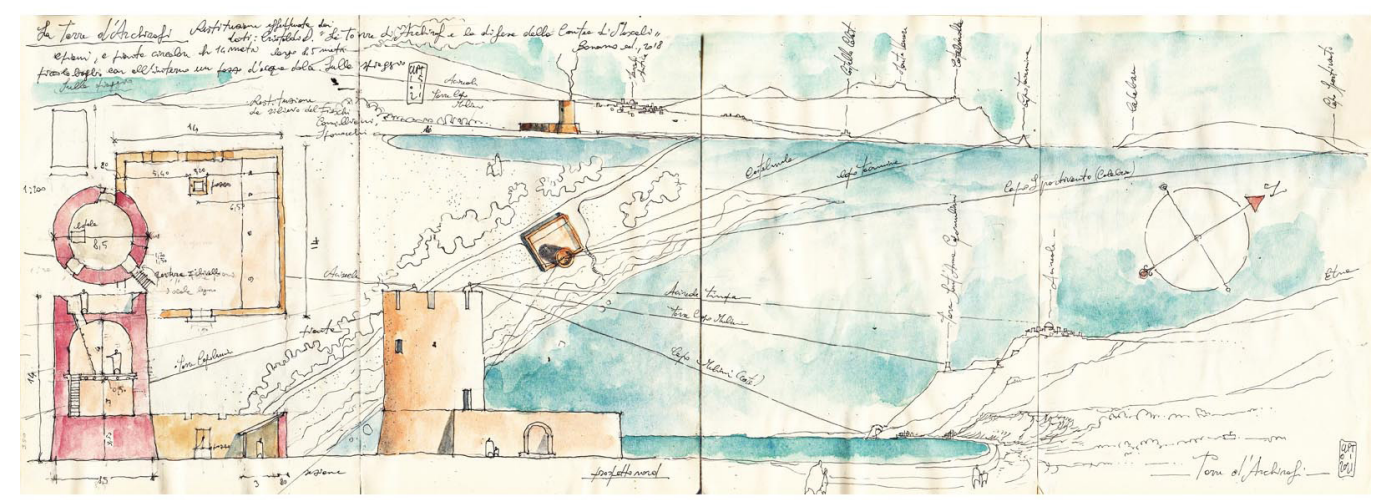




\section{Introduzione}

“'E dov'è la Fortezza allora?' chiese Drogo, improvvisamente irritato contro quell'uomo. 'Che Fortezza? Forse quella?' e così dicendo lo sconosciuto tendeva un braccio, ad indicare qualcosa" [Buzzati 1998, p. 7].

L'ambito che tratteremo in questo contributo, fa riferimento ad un progetto di rigenerazione di un itinerario culturale percettivo fatto di piccole architetture militari (torri, piazzeforti, fortilizi bastionati, garitte e così via) ormai scomparse, disseminate in maniera puntiforme lungo il paesaggio costiero siciliano. Architetture-sentinella contro gli assalti pirateschi, costruite per la maggior parte durante l'epoca Viceregnale spagnola ed il Regno Borbonico tra i secoli XVI e XVIII secolo. In particolare viene individuato quel breve ambito geografico relativo alla costa nord orientale della Sicilia, bagnata dal Mar lonio e sovrastato dall'imponenza del vulcano Etna. A $30 \mathrm{~km}$ a nord di Catania, superato l'irto promontorio delle antiche gradinate laviche etnee della Timpa di Acireale, si discende verso un fertile territorio un tempo appartenente alla Contea di Mascali, feudo fondato nel XVI sec., comprendenti oggi i comuni di Mascali, Fiumefreddo, Piedimonte Etneo, Giarre, Sant'Alfio, Milo, Santa Venerina e Riposto. Quest'ultima città, per la sua posizione geografica, d'innanzi al Mar lonio, fu in passato un borgo marinaro, "luogo di magazzini nei quali si 'ripostavano' i vini delle decime della Contea”" [lachello 1991, p. 26] e porto per trafficarne i prodotti agricoli e quant'altro di redditizio generava la terra. La Contea fu dotata nel tempo di torri di guardia poste sul territorio collinare e sulla costa a difesa dalle scorrerie piratesche. Se ne contavano, addirittura sette, oggi non più visibili, se non fosse solo per la presenza di poche tracce, ruderi, ma soprattutto documenti e memorie sparse tra antiche mappe, disegni e descrizioni delle ricognizioni fatte dagli architetti militari e cartografi tra il $X V I$ e il $X X$ sec. "Forse l'oblio sarebbe stato proprio il degno epilogo della storia di questo litorale in passato cinto di torri e ridotte, che la mano umana non è stata capace di preservare,

Fig. I. Inquadramento territoriale della Contea di Mascali e localizzazione delle due Torri Laviefuille e d'Archirafi nel territorio di Riposto (Catania) Ortofoto estrapolate da Google Earth Pro 2020 e Cartografia IGM.

Fig. 2. La Torre d'Archiraf disegnata da Camillo Camilliani (I584 c.) e da Tiburzio Spannocchi (1578 c.). Gentile concessione c.). Gentile concessione
di Salvatore D'Urso da Riposto (Catania).
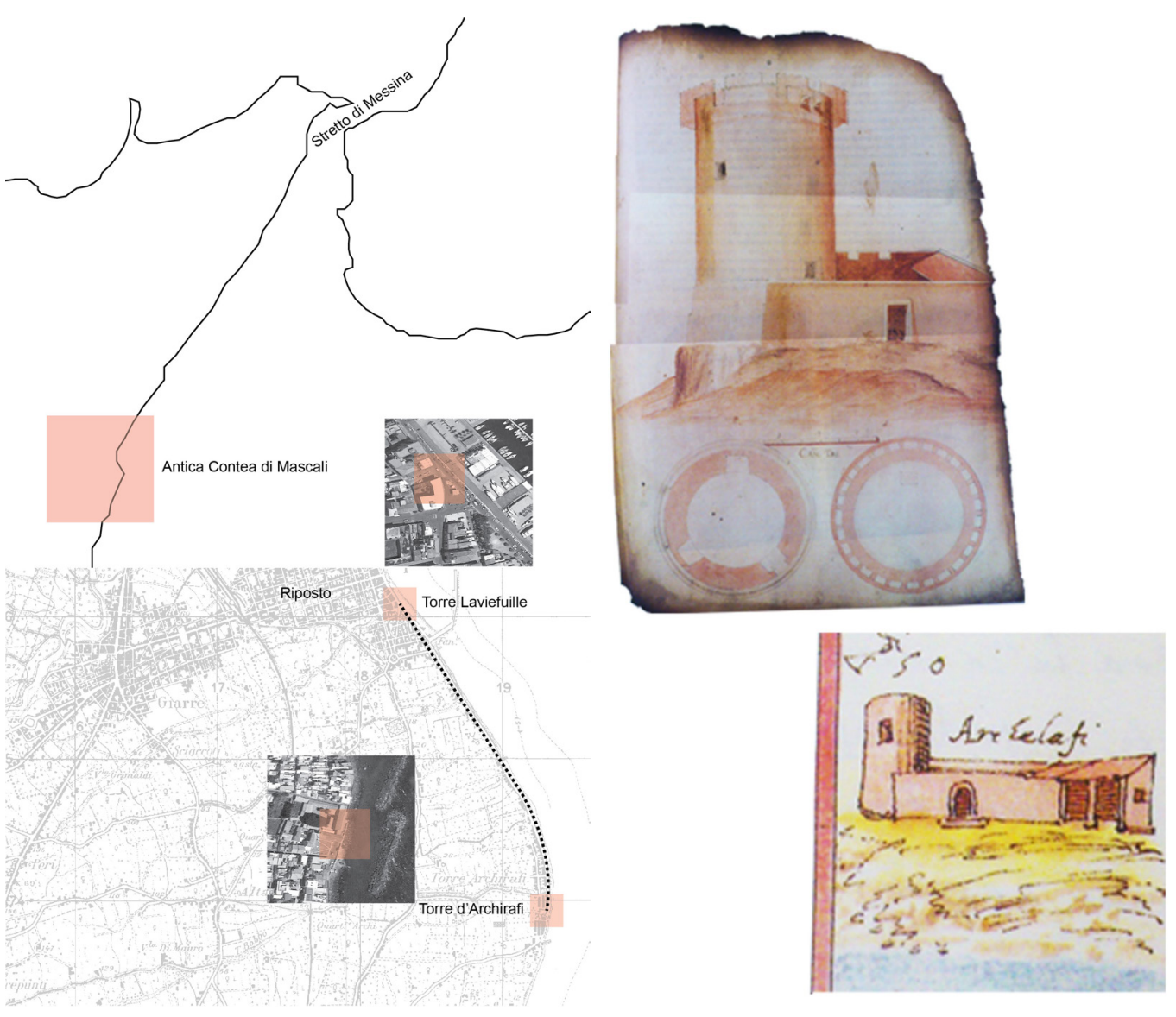
mentre solerte ha distrutto" [Cristaldi 20I8, p. I4] e fu questa la sorte toccata alle due torri d'Archirafi e Laviefuille oramai invisibili nel territorio di Riposto, l'una distrutta dagli agenti atmosferici: marosi, venti impetuosi e dalla noncuranza dell'uomo, l'altra abbattuta volontariamente dall'amministrazione locale nel 1925.

\section{Stato dell'arte}

Questa invisibilità è stata sempre fonte di una ricerca appassionata di molti storici di architettura militare locale, che nel tempo sono riusciti ad individuarne la corretta collocazione di entrambe le torri sul litorale, come nella pregevole ricerca e messa in ordine effettuata dallo studioso Davide Cristaldi con il suo scritto del 2018 sulle difese della Contea di Mascali. L'inedita disamina del nostro, ha portato, gli autori del presente contributo, a sviluppare una ricerca volta a riportare in superficie questi due manufatti del passato, con l'obiettivo di rigenerare un territorio ricco di memorie e 'archeologie latenti' dimenticate, mediante un museo diffuso a scala territoriale: l'tinerario storico-culturale del patrimonio delle torri di guardia della Contea di Mascali.

\section{Metodologia e research questions}

Il progetto, ancora in fase preliminare, mette in connessione le prime due torri d'Archirafi e Laviefuille distanti solo alcuni chilometri l'una dall'altra sul litorale di Riposto (fig. I). Dalla poca, ma soddisfacente documentazione cartografica e fotografica siamo riusciti, immedesimandoci nel progetto dell'anonimo architetto militare che le generò, prima a immaginarle, poi a

Fig. 3. Claudio Patanè, etrie dello sguardo (dettaglio), 2021. Restituzione geometrico critica (planta, sezione e Archirafi Acquerello e Archirafi. Acquerello e inchiostro su carnet de voyage.

Fig. 4. Elaborazione del modello tridimensionale solido della Torre d'Archirafi. Viste assonometriche e spaccato assonometrico (modellazione di

Dario Calderone)

Dario Calderone).

Fotoinserimento

Torre Archirafı

nel contesto attuale

Claudio Patanè).

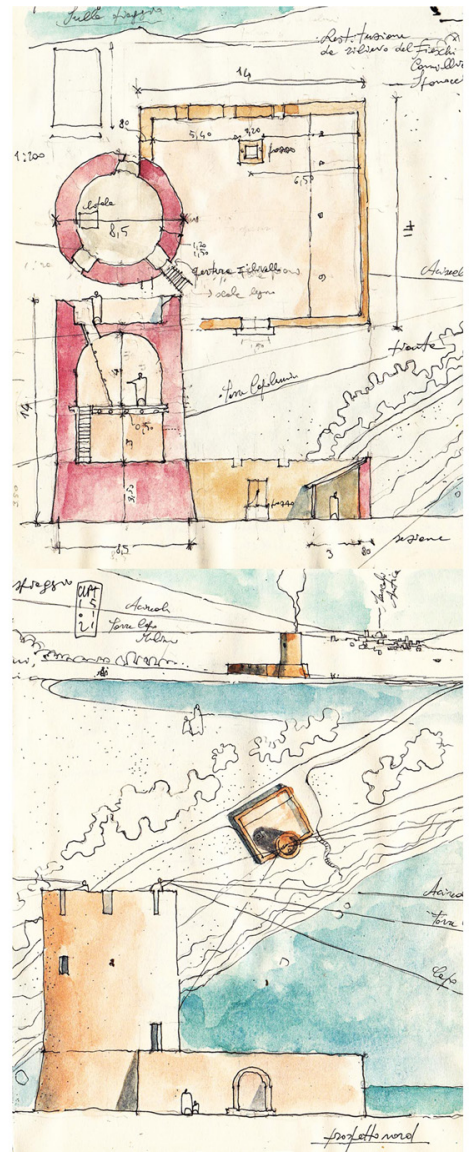

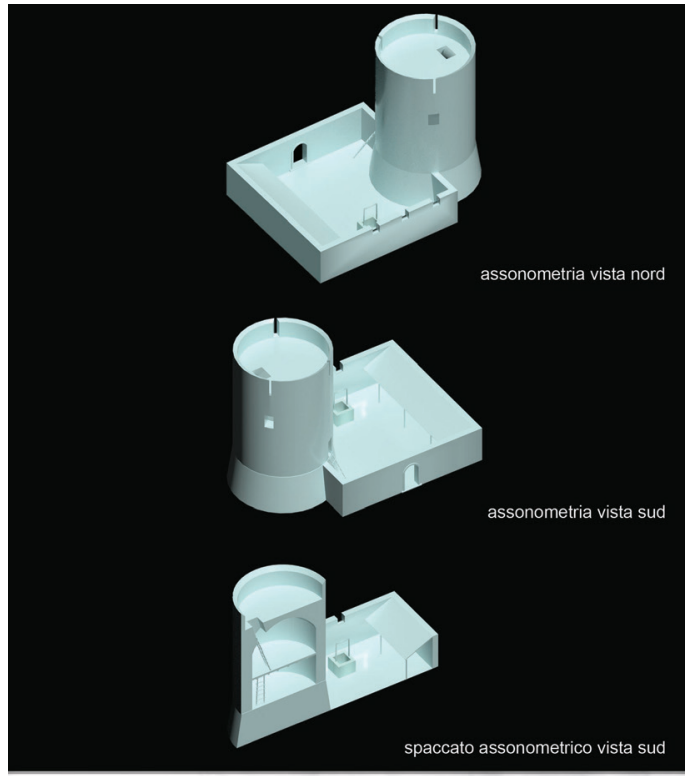

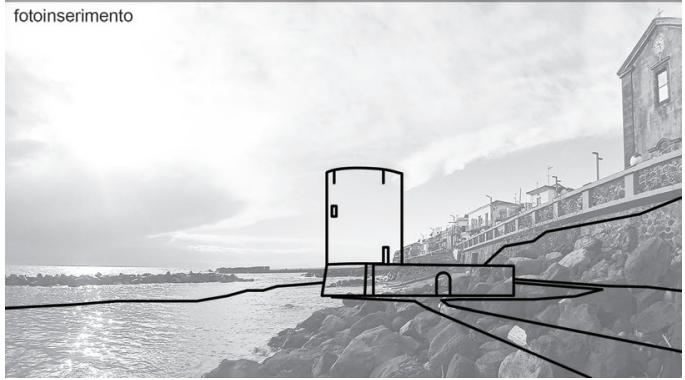


rivelarle, disegnarle e infine ricostruirne i modelli. Attestandone la loro possibile veridicità di architetture come machinationes, macchine del tempo incapaci di muoversi lungo il tempo, ma capaci di "muovere il tempo [...] specializzate nel produrre ritardo. La vera arma della fortezza sarà (n.a.) dunque la lentezza, l'attesa, dilatare il tempo fino a renderlo inoffensivo" [Del Giudice 2007, p. 30].

L'itinerario permetterà all'abitante-visitatore, di prendere parte di un percorso immersivo tra percezione analogica e multimediale. Stimolandolo mediante architetture e spazi dedicati, per la conoscenza del proprio passato e delle proprie origini culturali.

'Archeologie invisibili', dunque, nel tentativo di ricostruire non solo la fisionomia strutturale delle torri, così come già avvenuto, ma anche di comprendere meglio quale potesse essere il rapporto tra i suddetti sistemi difensivi e la morfologia del territorio. Allo scopo di ricostruire anche altri fattori determinanti come la viabilità e la distribuzione degl'insediamenti. Da ciò è risultato fondamentale la creazione di un'apposita piattaforma GIS, capace d'indicare con precisione l'esatta collocazione spaziale delle torri, degl'insediamenti e di tutti quegli altri aspetti che, riportati su cartografia, hanno fornito risposte importanti sulle modalità attraverso le quali l'area lonico-etnea "mascalese" venne occupata a cavallo tra il XVI e XIX secolo. Dalla quale, partendo da quest'ultime osservazioni si può cercare di capire fino a che punto la distribuzione delle torri si appoggiasse anche a precedenti strutture d'epoca medievale o se, di contro, la loro distribuzione fosse figlia di piani logistici esclusivamente moderni [I].

Quelli sopradescritti sono quesiti dalla difficile risoluzione, ma che senza dubbio grazie all'utilizzo delle nuove tecnologie possono essere affrontati con un maggior grado di consapevolezza, come ampiamente dimostrato dalla ricca letteratura esistente sull'utilizzo delle piattaforme GIS per la lettura integrata dei contesti antichi, archeologici e della morfologia del territorio [2].

Fig. 5. La Torre Laviefuille in due cartoline e una foto d'epoca, 1900. Gentile concessione di Gaetano Cannavò e Vera Pennisi da Riposto (Catania).

Fig. 6. Claudio Patanè, Restituzione geometrico/ critica (schizzi iniziali, piante, sezioni, prospetti e viste prospettiche) della viste prospettiche) dela Acquerello e inchiostro su carnet de voyage.



\section{Casi studio}

Della torre d'Archirafi avevamo come riferimenti le descrizioni, i rilievi e i disegni dell'esistente e di restauro effettuate durante le ricognizioni tra il I 578 ed il I 584 da Tiburzio Spannocchi, Giovan Battista Fieschi Garaventa e Camillo Camiliani (fig. 2). Lo storico Cristaldi così trascrive l'estratto dalla relazione effettuata dal Fieschi, attuando le dovute conversioni da palmi e canne al sistema metrico decimale:"La Torre di Archirafi si presenta come una struttura di due piani a pianta circolare, dell'altezza di circa 14 metri, larghezza di circa 8,5 metri e affiancata da un piccolo baglio, all'interno del quale è presente un pozzo d'acqua dolce" [Cristaldi 20I8, p. 3I]. La torre, all'epoca dei fatti, versava in condizioni conservative precarie, riconducibili all'azione erosiva degli eventi atmosferici di questo territorio, che porterà alla sua lenta e definitiva scomparsa intorno alla metà del XIX sec. Nella Descrttione dell'isola di Sicilia [Scarlata 1993, p. 539] Camillo Camilliani oltre ad un'attenta rappresentazione grafica della torre, in cui conferma l'impianto circolare e la presenza del rivellino perimetrale, propone un progetto di manutenzione e messa in sicurezza della stessa. Ne dà conferma della sua geometria e forma anche Tiburzio Spannocchi nella sua ricognizione avvenuta precedentemente nel 1578, mediante una descrizione capillare del territorio in cui sorgeva la torre d'Archirafi, delle distanze e connessioni con le altre fortezze circostanti e della funzione predominante di controllo e difesa della Contea di Mascali. La torre si relazionava a sud con il promontorio ove era collocata la Torre di Sant'Anna di Capo Mulini nel territorio di Acireale e a nord con la fortezza di Castelmola, oltra ad avere un'ampia visibilità con la costa calabra e dello Stretto di Messina.

La ricostruzione grafica analogica (schizzi preliminari, pianta, prospetti e sezioni) (fig. 3) ed il modello tridimensionale della torre, e quindi la resa virtuale e dinamica della stessa mediante fotoinserimento (fig. 4), sono stati elaborati dalla disamina della documentazione illustrata.

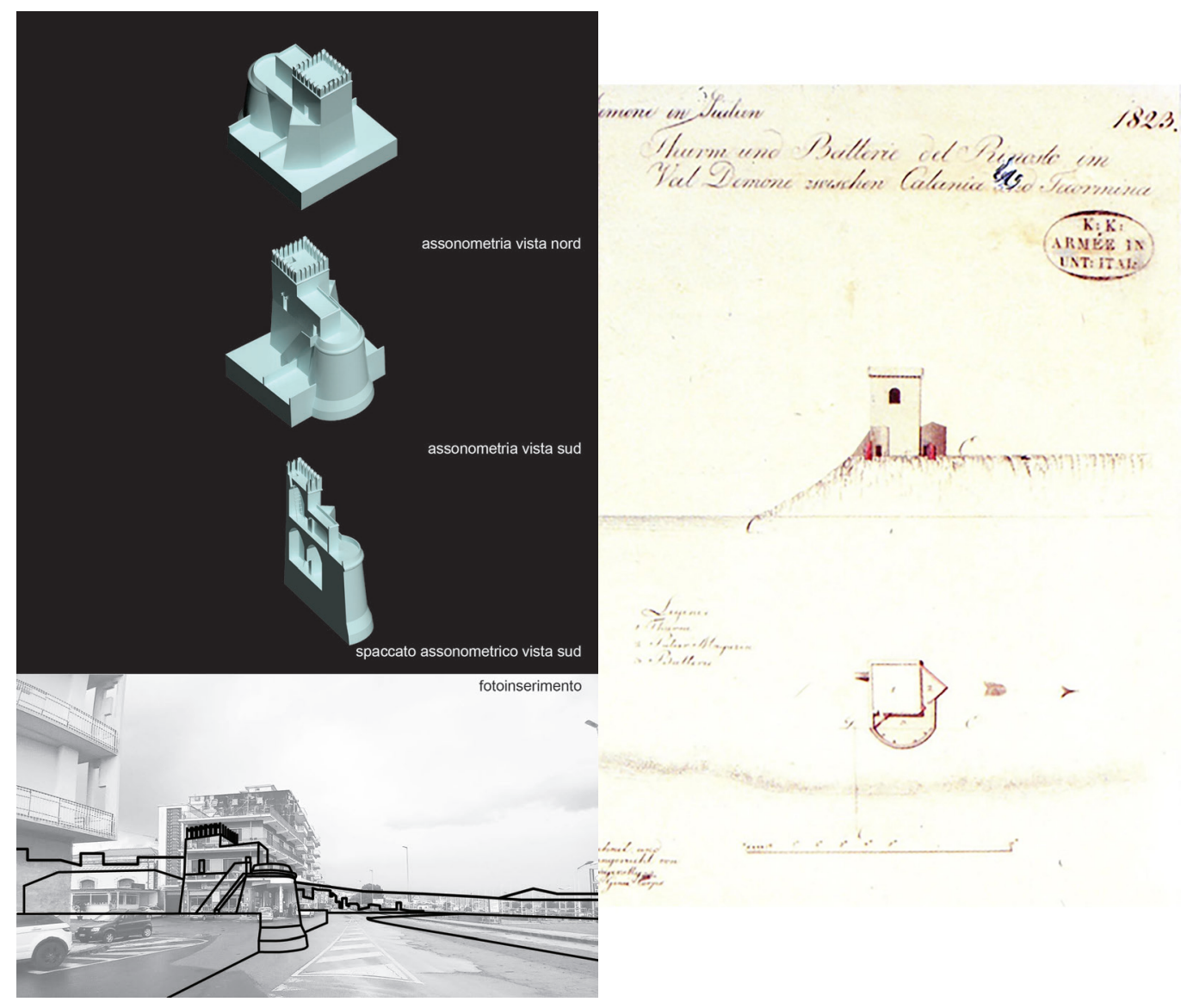


Fig. 9. Claudio Patanè, Disegno della 'stanza' (camera chiara), 2021. Piattaforma narrativa/ informativa analogica, localizzata a pelo d'acqua, nel contesto in cui sorgeva la Torre di Archirafi. Lo storico palazzo Vigo ospiterà 'stanza' (camera osera digitale per la realtà immersive la realta Acquerelo incino su carnet de voyage.

Fig. 10. Claudio Patanè, Disegno della 'stanza' (camera oscura), 2021. Spazio narrativo/ informativo analogico digitale, localizzato nel contesto in cui sorgeva la Torre di Laviefuille. La realizzazione dello padiglione permetterà padiglione permettera ridre di pidefire e nidare qualita allo spaz urbano. Acquerello e su carnet de voyage.
Lo studio diretto delle proporzioni dettate dalla pura geometria della torre, l'analisi del corollario stilistico e tipologico confrontato con altre torri della stessa epoca, ha restituito un disegno controllato dalla misurazione, ottenendo una sorta di rilevamento "rovesciato". Inoltre ha permesso di sviluppare una risemantizzazione del manufatto visibile e del suo progetto inserito in un contesto oggigiorno difforme da come doveva presentarsi in passato. Differente il caso della torre Laviefuille, costruita forse per sostituire la torre d'Archirafi, ormai in macerie. La sua costruzione risale infatti al 1752 "quando fu edificata una nuova struttura difensiva, secondo il volere del vicerè Eustachio Laviefuille, per la protezione del caricatore di Riposto" [Cristaldi 2018, p. 55]. La torre fu "inconsultamente" [Correnti 1985, p. 166] abbattuta dal sindaco del borgo marinaro nel 1925.

In mancanza di documentazione soddisfacente la disamina è avvenuta attraverso un repertorio fotografico ( $X X$ sec.) e cartografico (fig. 5) che ne ha permesso la ricostruzione grafica analogica, schizzi preliminari e le restituzioni ortogonali di piante, prospetti e sezioni (fig. 6). Ne è seguita la costruzione del modello tridimensionale con un ulteriore confronto dimensionale e geometrico sul tessuto urbano mediante fotoinserimento (fig. 7).

II forte si presentava con un bastione avanzato ad impianto circolare troncoconico con cordone sommitale marcapiano e basamento in pietra lavica. Inglobava un torrione ad impianto quadrangolare rastremato fino al vano superiore. II prospetto esposto a nord, in mancanza di repertorio fotografico è stato ricavato dalla disamina di un rilievo del 1823 (fig. 8) [Russo 1994, p. 536]. Ne consegue una ipotesi di ricostruzione a completamento del fortilizio, con il torrione ad impianto quadrangolare inglobato dal rafforzamento della rastremazione, che a settentrione avanzava come bastione saliente e terrazzato. Esso era collegato da una passerella alla piazza d'armi del bastione circolare esposto verso il mare. Si ipotizza che l'interno fosse suddiviso in due livelli, un primo livello all'interno del corpo bastionato con due vani voltati e connessi mediante una scala in legno al vano superiore, collegato mediante una botola alla terrazza merlata. Una superfetazione costruita posteriormente si sovrappone alla piazza d'armi del bastione circolare.

II forte doveva presentarsi incastonato tra la quota del terrapieno del borgo marinaro, più alta rispetto al livello del mare. Ne consegue l'ipotesi che il bastione circolare fu costruito come contenimento e rafforzamento al torrione quadrangolare già preesistente.

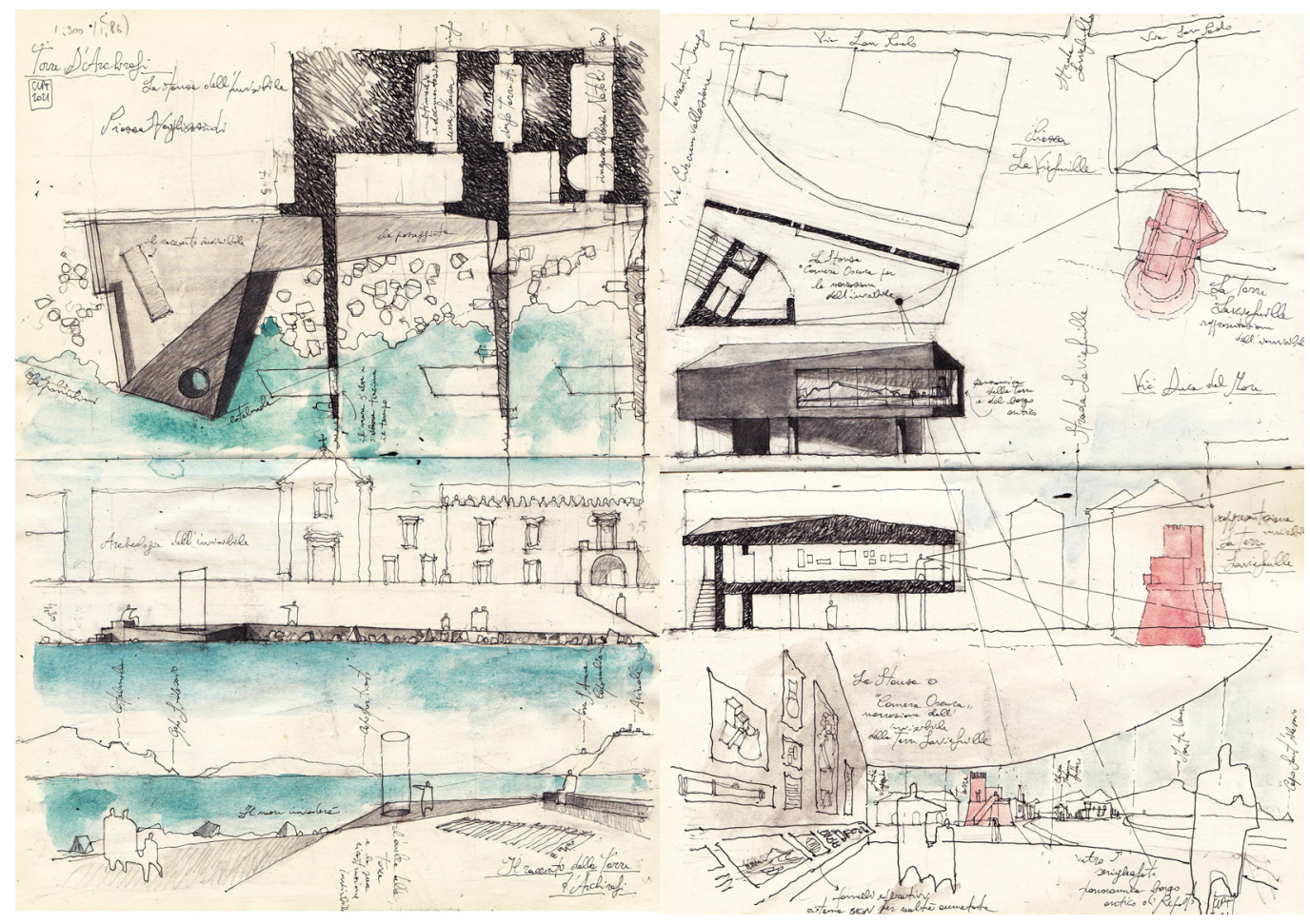




\section{Conclusioni}

Dal lavoro di restituzione e ricostruzione dei due artefatti, eseguito in modalità "mista" [Patanè 2020, pp. 157-165] analogica e digitale; dal confronto degli elaborati disegnati tramite tecniche classiche di rappresentazione diretta e tramite la costruzione di un modello virtuale, è scaturita la necessità di progettare un itinerario museale diffuso che mettesse in connessione le due 'architetture invisibili'. L'inizio e il completamento dell'itinerario saranno segnati dalla presenza di due 'stanze narrative', o padiglioni, che raccontino la storia e la loro connessione con un sistema territoriale più ampio, facente capo a quello dell'antica difesa della Contea di Mascali, del suo paesaggio terracqueo e del suo entroterra. Le 'stanze' saranno degli spazi costruiti che riqualificheranno il contesto urbano in cui le torri d'Archirafi e Laviefuille erano collocate. La 'stanza', sarà un dispositivo spaziale, attraversabile dagli abitanti/visitatori che ne faranno momento esperenziale interattivo tra realtà e virtualità. "Non si tratta di restituire in modo identico ciò che è stato demolito ma di fare appello alla memoria degli abitanti attraverso una serie di richiami, dando al centro storico una nuova dimensione. Questa pratica permette agli architetti di collegare l'esistente al passato ma anche di mettere in rilievo, degli stessi luoghi, elementi nuovi e specifici che ne garantiscono l'identità" [Burkhardt I999, p. 34].

Nel caso della torre d'Archirafi una 'camera chiara' all'aperto farà da piattaforma, tra cielo e mare, sul paesaggio terracqueo, a pelo d'acqua, ricordando la presenza del forte come costruzione di un giacimento archeologico riemerso in superficie attraverso le tracce del passato (fig. 9). "La mossa proposta è quella di conferire spessore al suolo" [Viganò I999, p. $|8|$ ] al limite dell'orizzonte del mare, in cui il tracimare dei flutti attribuisca inediti significati di assenza, scomparsa e oblio. II disegno costruisce questa volontà di legarsi all'invisibile mediante simboli e geometrie. II cilindro vuoto della torre, scavato dall'acqua del mare, forato e

Fig. I I. Immagine esemplificativa di dispositivi digitali per l'iterazione immersiva e virtuale della Torre di Archirafi (elaborazione grafica e modellazione Claudio Patanè e Dario Calderone).

\section{Fig. 12. Mappa}

"'ttinerario dell'invisibile. Connession del patrimonio latente dell'antica Contea di Mascali'. II diagramma rappresenta, una inedita mappa concettuale, costruita dalle connessioni intermittent tra le due torri d'Archirafi e Laviefuille con il restante sistema difensivo del territorio della Contea di Mascali. ella Contea di Masca con quelle tracce visibil o invisibili di carattere p invibili di carattere paesaggistico, antropico
archeologico e urbano.
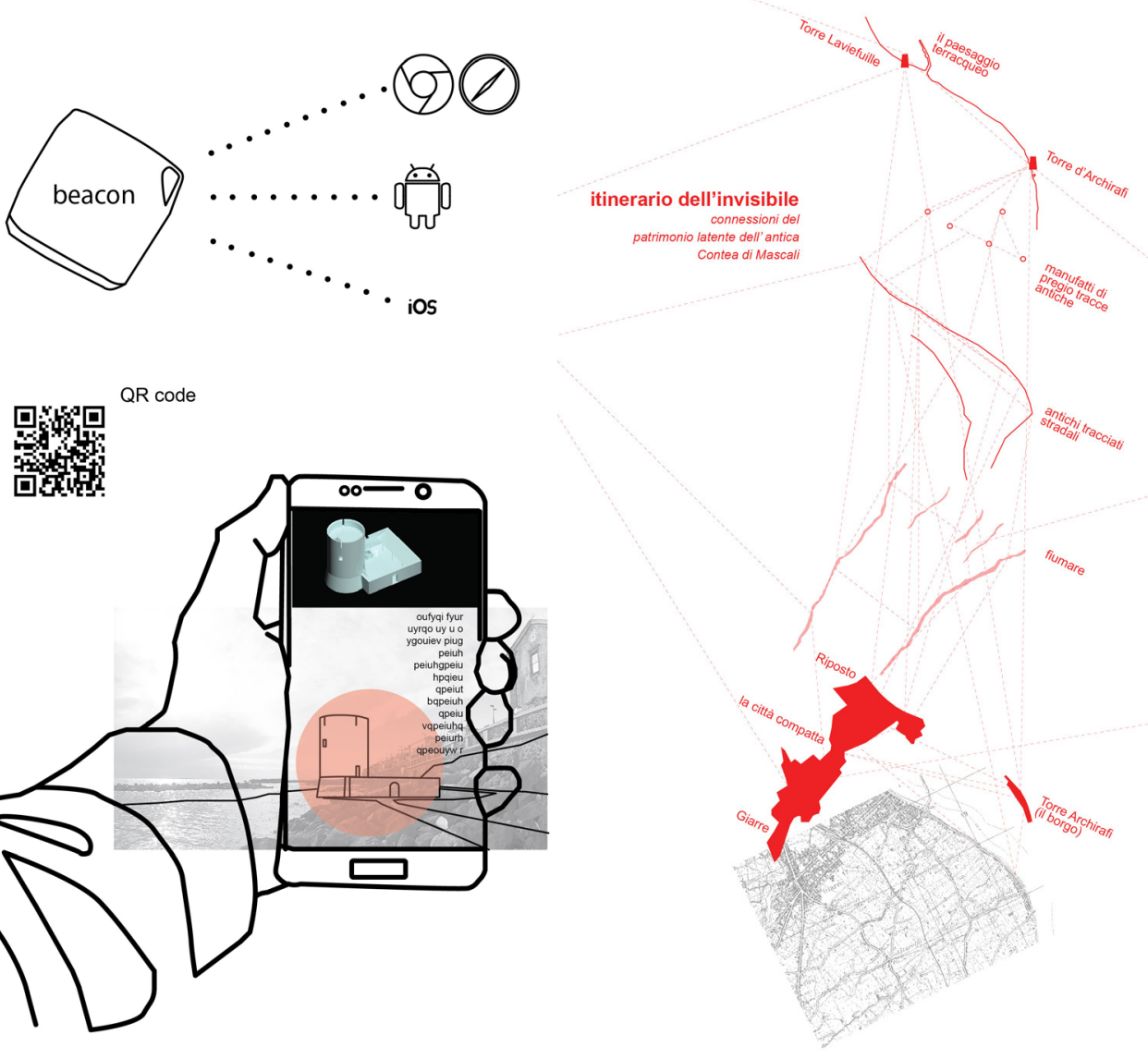
inclinato sulla piattaforma che sarà direzionata verso Castelmola e Torre Sant'Anna di Capo Mulini. Narrazioni incise sul pavimento e sedute, per con-templare e costruire un orizzonte fatto di cielo e di mare. Una "camera oscura", multimediale, all'interno dello storico Palazzo Vigo permetterà d'interagire scientemente alla documentazione storica ed alla rappresentazione virtuale del passato della torre.

II contesto della torre Laviefuille è ricco di contraddizioni ed eccessi di carattere edilizio-speculativo e infrastrutturale per il fronte mare della città di Riposto. Restano solo tracce impercettibili nelle perimetrazioni degli isolati, ma ne sono mutati i caratteri morfologici e orografici di aderenza, approdo e affaccio verso il mare. La sezione del sedime stradale si è slabbrata, aumentandone il carico carrabile. L'attuale porto turistico ha allontanato definitivamente "lo sguardo del mare [...] 'personificazione' della distesa equorea" [Purpura 20 I0, p. 13] che guardava l'abitante, oggi ormai distratto e disinteressato. La 'stanza narrativa' della torre Laviefuille, si presenta come una 'camera oscura', il cui spazio catalizzerà l'immagine dell'antico borgo marinaro, della sua torre e della Contea di Mascali e le proietterà dal suo interno. Una proiezione panoramica su vetro serigrafato rappresenterà la città antica e il suo fortilizio. L'abitante/visitatore interagirà con dispositivi per la realtà immersiva e dispositivi a contatto diretto per consultare, toccare, immaginare, inventare ciò che è scomparso. La costruzione della 'stanza narrativa', si ergerà sospesa su di uno vuoto urbano, legando e ricucendo quel tessuto di città ormai privo di qualità architettonica e urbana. La costruzione di questo spazio sospeso seguirà le tracce oramai invisibili dell'antica foce del Torrente Jungo, oggi via Circumvallazione-Largo Carmine e il tracciato longitudinale dell'odierna Via Duca del Mare (fig. I0).

Combinando I'utilizzo dei modelli tridimensionali e delle informazioni inserite all'interno delle piattaforme GIS sarà possibile infine dar vita a quei processi di valorizzazione e promozione del patrimonio basate anche sulla realtà aumentata [Solima 2019, pp. 177-215], tecnologia che sta riscuotendo tra gli addetti ai lavori del settore culturale, così come del suo pubblico di riferimento, un crescente apprezzamento. L'elaborazione di applicazioni culturali basate sull'utilizzo della realtà aumentata [Bonacini 20I4, pp. 89-III] (fig. II), renderà la digitalizzazione del patrimonio architettonico e archeologico dell'antica Contea, una risorsa molto importante anche per il suo territorio protagonista della nostra ricerca, allo scopo di tutelarne la memoria di luoghi e contesti che pur non essendo più esistenti fisicamente, possono ancora trasmettere cultura e conoscenza attraverso le nuove e innovative forme di fruizione (fig. 12). "Mettere in relazione un sistema puntuale di manufatti, esistenti e non, costituito dalle torri d'avvistamento, per renderle 'chiavi' di un sistema di luoghi della cultura e carattere diffuso, che 'avvista e accoglie' in forma tangibile, palpabile, quell'orizzonte fatto di mare o di terra, di storia, di memoria e di conoscenza" [Fatta 2019, p. 902].

\section{Ringraziamenti}

Gli autori ringraziano Maria Coppolino, Davide Cristaldi, Salvatore D'Urso, Gaetano Cannavò e Vera Pennisi per il supporto dato a questa ricerca.

\section{Note}

[I] Anche in quest'ottica la restituzione digitale degli edifici perduti si rivela fondamentale allo scopo di avviare analisi approfondite dell'architettura dei monumenti atte all'eventuale individuazione di componenti architettoniche relative a periodi precedenti al XVI secolo.

[2] L'utilizzo delle applicazioni GIS allo scopo di ricostruire le logiche con cui veniva gestito e occupato un determinato territorio nell'antichità, in campo archeologico ha sviluppato un approccio metodologico ben definito. Per ulteriori esempi, che ben descrivono le possibilità offerte dall'approccio in questione vedi: [Gioia 20 I6, pp. I37-|48]; [Calderone 2020, pp. 75-88]; [Pizziolo 2017, pp. 381-387]

\section{Riferimenti bibliografici}

Bonacini E. (20|4). La realtà aumentata e le app culturali in Italia: storie da un matrimonio in mobilità. In II capitale culturale Studies on the Value of Cultural Heritage. vol. 9, pp. 89- I I I.

Buzzati D. (1998). Il deserto dei Tartari. Milano: Mondadori. [Prima ed. II deserto dei Tartari. Milano I940]. 
Burkhardt F. (1999). Ricostruzione della Chiesa Madre e ridisegno di piazza Alicia e delle strade adiacenti, Salemi, Trapani. In Domus. n.813, pp.34-42.

Calderone D. (2020). Rotte e vie di comunicazione attraverso i monti Sicani durante il Neolitico: Ipotesi di viabilità di lunga durata tra Campofranco e Milena (CL). In Ipotesi di Preistoria. vol. I3, 2020, pp. 75-88.

Correnti S. (1985). RIPOSTO nella storia, nell'arte e nella vita del suo popolo. Catania:Tringale Editore.

Cristaldi D. (20 18). La Torre di Archirafı e le difese della Contea di Mascali. Acireale-Roma: Gruppo Editoriale Bonanno.

Del Giudice D., Scolari M. (2007). Un numeroso mondo. In Marzari G., (a cura di) Massimo Scolari. Milano: Skira.

Fatta F., Maraffa A., Patanè C., (2020). Geometrie dello sguardo nel paesaggio calabrese. In Palazón J.N., García-Pulido L..., (eds). FORTMED 2020, Defensive Architecture of Mediterranean. Atti del convegno Granada (ESP), vol. XI, pp. 899-906.

Gioia D., et al. (2016). A Geoarchaeological study of the Metaponto coastal belt, souther Italy, based on geomorphological mapping and GISsupported classification of landforms. In Geogr. Fis. Dinam. Quat. n. 39, pp. I 37 - I 48.

lachello E. ( I991). II vino e il mare. "Trafficanti” siciliani tra "700 e '800 nella Contea di Mascali. Catania: Maimone Editore.

Patanè C., et al. (2020). Farsi di/segno La Calzada de Béjar narrazione grafica di un borgo. In Agustín-Hernández L., Vallespín Muniesa A., Fernández-Morales A. (eds.). EGA Saragoza 2020. Atti del XVIII convegno. Springer, vol. III, pp. I57-I 65.

Pizziolo G., et al. (2017). II paesaggio archeologico del Gargano. In Radina F. (a cura di). Studi di Preistoria e Protostoria - 4 Preistoria e Protostoria della Puglia, tra Neolitico antico ed Eneolitico finale. Firenze: Istituto Italiano di Preistoria e Protostoria, pp. $38 \mid-387$

Purpura M. A. (20 I0). Lo sguardo del mare. Scrittori al confino e rappresentazione letteraria dell'immagine marina nel Novecento. Palermo: Gruppo Editoriale Kalós.

Russo F. ( 1994). La difesa costiera del Regno di Sicilia dal XVI al XIX secolo. Tomo I e II. Roma: Ufficio Storico Stato Maggiore Esercito.

Scarlata M. (1993). L'opera di Camillo Camilliani. Roma: Ist. Poligre Zecca dello Stato.

Solima L. (2019). Management per l'impresa culturale. Roma: Carocci ed.

Viganò P. (1999). La città elementare. Ginevra-Milano: Skira ed.

\section{Autori}

Claudio Patanè, Università Mediterranea di Reggio Calabria, claudio.patane@unirc.it

Dario Calderone, Università degli studi di Catania, dario.calderone@phd.unict.it

Per citare questo capitolo: Patanè Claudio, Calderone Dario (2021). L'invisibile rivelato. Disamina e progetto per un itinerario museale diffuso dell'antica Contea di Mascali/The invisible revealed. Analysis and plan for a widespread museum itinerary of the Ancient County of Mascali. In Arena A. Arena M. Mediati D Raffa P. (a cura di). Connettere Un disegno per annodare e tessere Linguaggi Distanze Tecnologie. Atti del $42^{\circ} \mathrm{Convegno}$ Internazionale dei Docenti delle Discipline della Rappresentazione/Connecting. Drawing for weaving relationship. Languages Distances Technologies. proceedings of the $42^{\text {th }}$ International Conference of Representation Disciplines Teachers. Milano: FrancoAngeli, pp. 1796-1813. 


\title{
The Invisible Revealed. Analysis and Plan for a Widespread Museum Itinerary of the Ancient County of Mascali
}

\author{
Claudio Patanè \\ Dario Calderone
}

\begin{abstract}
The texst presents a research and a design for the 'regeneration of the cultural heritage' of a specific geographical area, corresponding to the stretch of coastline that faces the lonian Sea and is rooted at the bottom of Etna, in Sicily. This "terracqueus landscape" has in the past been punctually marked by vertical architectures, the coastal watchtowers, which can be found all over the Mediterranean. Artifacts that, like "time machines", still allow us to travel motionless to contemplate that horizon made of sky and sea, which we contemporaries are all too familiar with by now, but where that elsewhere still reigns, reaching out towards a desire that unites the present, memory and the near future. Among these, the Archirafi and Laviefuille Towers are two military architectures that no longer exist, 'invisible', which stood on the coast of Riposto in the province of Catania, belonging to a much larger fortified system defending the Contea of Mascali. The study of these artefacts, the analysis, examination of texts, historical cartographies, maps, drawings of the past, their critical analogical drawing, restitution and 3D modelling, have led the authors to develop a strategic programme of regeneration of the 'invisible cultural heritage' of this portion of the terracqueous landscape. Developing new scenarios and itineraries between the real and the virtual, analogue and digital representation, with the aim of providing institutions and administrators who manage local heritage with pilot projects to bring to the surface and re-connect the distracted contemporary resident with those latent and invisible places that populate, albeit unconsciously, his memory.
\end{abstract}

Keywords

heritage, analogue drawing, digital drawing, invisible, watchtowers.

Claudio Patanè, 'Geometries of the gaze', 2021. Geometrical/critical restitution of the Archirafi Tower and its visual rower and its visual relationships with the surrounding landscape. Watercolour and ink on carnet de voyage.

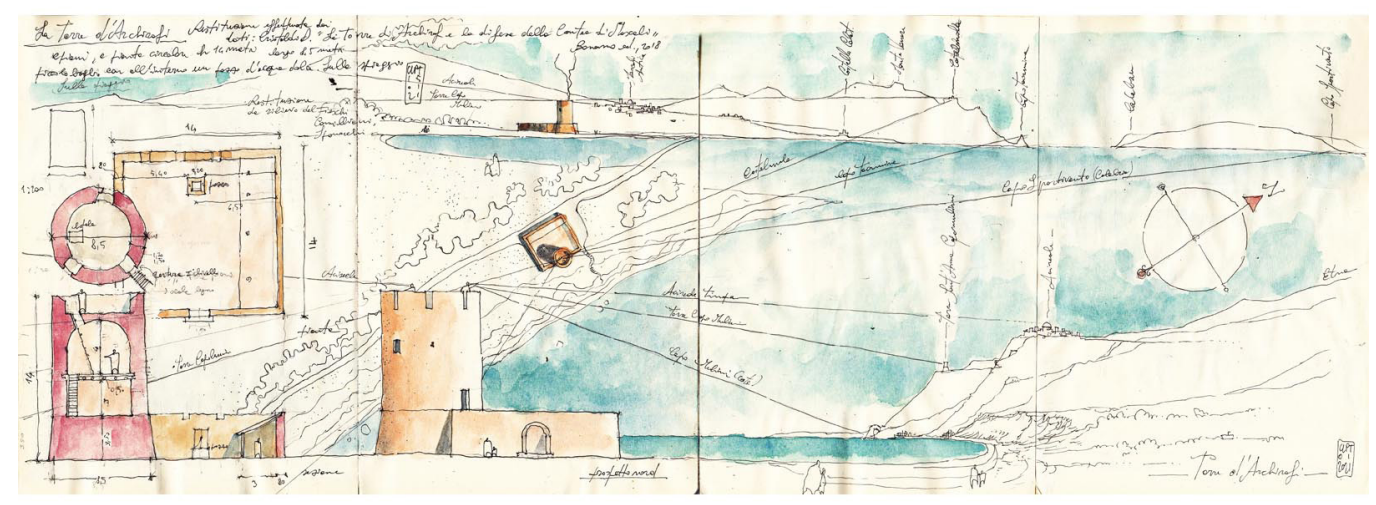




\section{Introduction}

"'Where is the Fortress then?' asked Drogo, suddenly irritated at the man. 'What Fortress? Perhaps that one?' and so saying the stranger held out an arm, indicating something"' [Buzzati 1998, p. 7].

The area addressed in this contribution refers to a designed to regenerate a perceptive cultural itinerary made up of small military architectures (towers, strongholds, bastioned forts, garitte, etc.) which have now disappeared, scattered in a punctiform manner along the Sicilian coastal landscape. Sentinel-architectures against pirate assaults, built for the most part during the Spanish Viceroyalty and the Bourbon Kingdom between the 16th and 18th centuries. In particular, the short geographical area of the north-eastern coast of Sicily, washed by the lonian Sea and dominated by the imposing Etna volcano, is identified. $30 \mathrm{~km}$ north of Catania, after passing the steep promontory of the ancient Etnean lava steps of Timpa di Acireale, we descend towards a fertile territory that once belonged to the Contea of Mascali, a feud founded in the 16th century and now comprising the municipalities of Mascali, Fiumefreddo, Piedimonte Etneo, Giarre, Sant'Alfio, Milo, Santa Venerina and Riposto. This last city, for the geographical position on the lonian Sea, was in the past a fishing village, "a place of warehouses in which the wines of the county's tithes were stored". [lachello 199I, p. 26] and port to traffic in agricultural products and whatever else the land generated. Over time, the county was equipped with watchtowers on the hills and on the coast to defend it from pirate raids. There were as many as seven of them, which are no longer visible today, if it were not for the presence of a few traces, ruins, but above all documents and memories scattered among old maps, drawings and descriptions of the survey carried out by military architects and cartographers between the 16th and 20th centuries. "Perhaps oblivion would have been a fitting end to the history of this coastline, once girded with

Fig. I. Territorial overview of the Contea di Mascali and location of the Laviefuille and d'Archirafi Towers in the territory of Riposto (Catania). Orthophotos extrapolated from Google Earth Pro 2020 and IGM Cartography.

Fig. 2. The Archirafi Tower surveyed by Camillo Camilliani (c. 1584) and Tiburzio Spannocchi Tc. 1578) Countesy (c. 1578). Courtesy of Riposto (Catania).
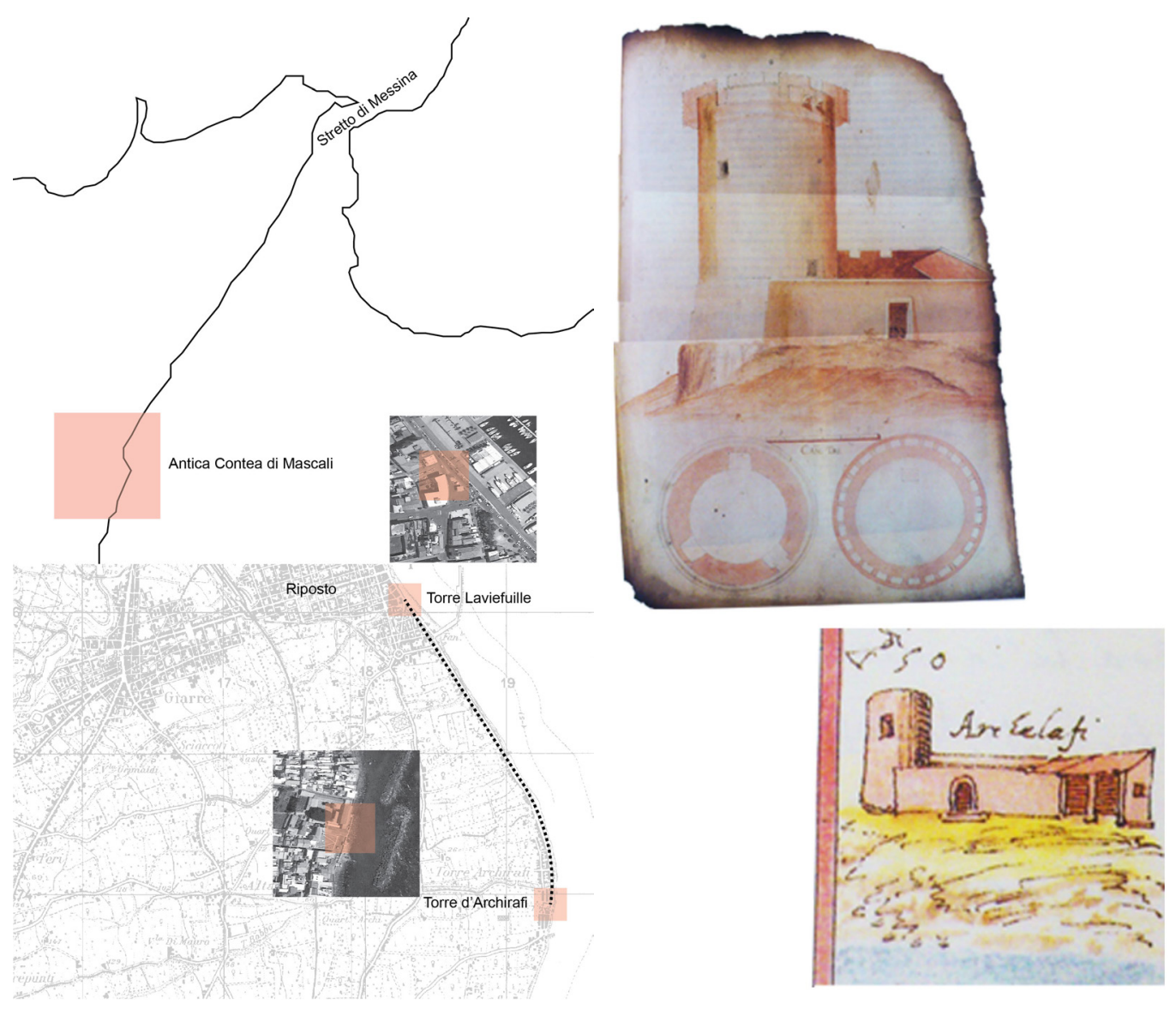
towers and redoubts, which the human hand has been unable to preserve, while zealously destroying". [Cristaldi 20 I8, p.I4] and this was the fate of the two towers of Archirafi and Laviefuille, now invisible in the territory of Riposto, one destroyed by the atmospheric agents: heavy seas, strong winds and human carelessness, the other demolished voluntarily by the local administration in 1925.

\section{State of the art}

This invisibility has always been the source of passionate research by many historians of local military architecture, who over time have identified the correct location of both towers on the coast, as in the valuable research and tidying up carried out by researcher Davide Cristaldi with his 2018 paper on the defences of the Contea di Mascali. The unprecedented examination of our area has led the authors of this contribution to develop a research project aimed at bringing these two artefacts of the past to the surface, with the objective of regenerating a territory rich in memories and forgotten 'latent archaeologies', by means of a widespread museum on a territorial scale: the historical-cultural itinerary of the heritage of the watchtowers of the Contea di Mascali.

\section{Methodology e research questions}

The project, which is still in its preliminary phase, connects the first two towers of Archirafi and Laviefuille, which are only a few kilometres apart on the Riposto coastline (fig. I). From the scarce but satisfactory cartographic and photographic documentation we were able, by

Fig. 3. Claudio Patanè, Geometries of the gaze (detal), 202l. Geometric/ critical restitution (plan, section and elevation) of the Archirafi Tower. Watercolour and ink on carnet de voyage.

Fig. 4. Elaboration of the 3D solid model of the Archirafi Tower Axonometric views and cross-section (modelling by Dario Calderone). Archirafi Tower in its curchirafi context (graphic elaboration by Claudio Patanè).

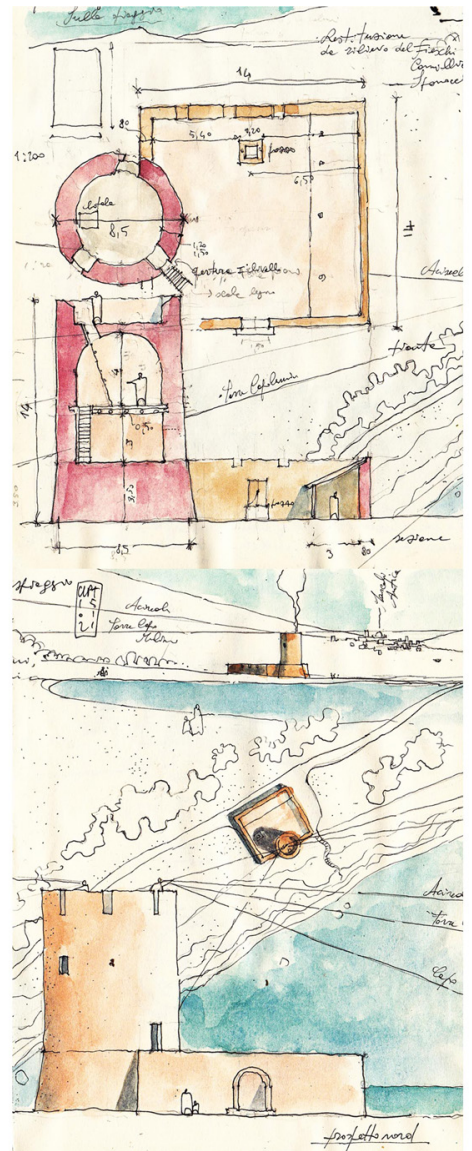

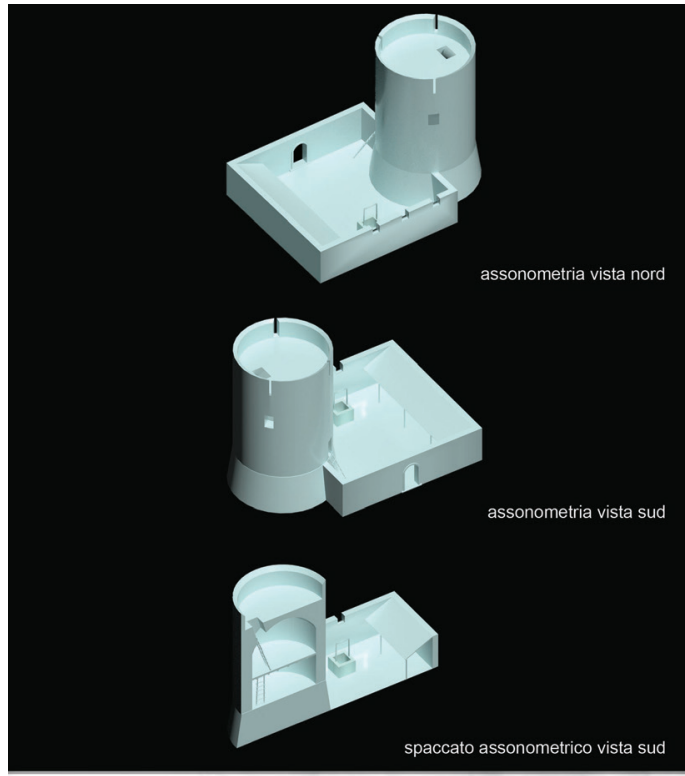

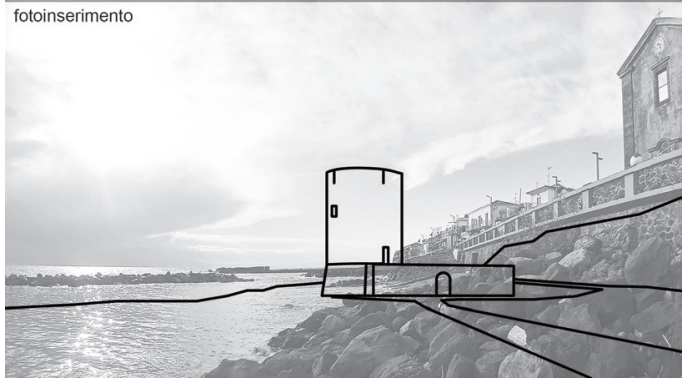


identifying ourselves with the design of the anonymous military architect who created them, first to imagine them, then to reveal them, draw them and finally reconstruct the models. Attesting to their possible veracity of architectures as 'machinationes', time machines incapable of moving along time, but capable of '"moving time' [... 'specialised in producing delay. The real weapon of the fortress will (n.a.) therefore be slowness, waiting, dilating time until it becomes inoffensive"' [Del Giudice, Scolari 2007, p. 30].

The itinerary will allow the inhabitant-visitor to take part in an immersive journey between analogue and multimedia perception. Stimulating him through dedicated architectures and spaces, for the knowledge of his own past and cultural origins.

'Invisible archaeologies', therefore, in an attempt to reconstruct not only the structural physiognomy of the towers, as has already been done, but also to better understand what the relationship between these defensive systems and the morphology of the territory might have been. In order to reconstruct other determining factors such as the road network and the distribution of settlements. This made the creation of a dedicated GIS platform essential, capable of indicating the exact spatial location of the towers, the settlements and all those other aspects that, shown on the map, have provided important answers as to how the Ionian-Etnean 'Mascalese' area was occupied between the 16th and 19th centuries. On the basis of the latter observations, we can try to understand to what extent the distribution of the towers was also based on previous medieval structures or whether, on the contrary, their distribution was the result of exclusively modern logistical plans [I].

These questions are difficult to solve, but thanks to the use of new technologies they can be addressed with a greater degree of awareness, as amply demonstrated by the rich literature on the use of GIS platforms for the integrated reading of ancient contexts, archaeology and morphology of the territory [2].

Fig. 5. The Laviefuille Tower in two postcards and a historical photo (1900). Courtesy of Gaetano Cannavò and Vera Pennisi from Riposto (Catania).

Fig. 6. Claudio Patanè, Geometric/critical restitution (initial sketches, plans, sections, elevations and sections, elevations and
perspective views) of the perspective views) of the
Laviefuille Tower, 2021. Watercolour and ink on carnet de voyage.
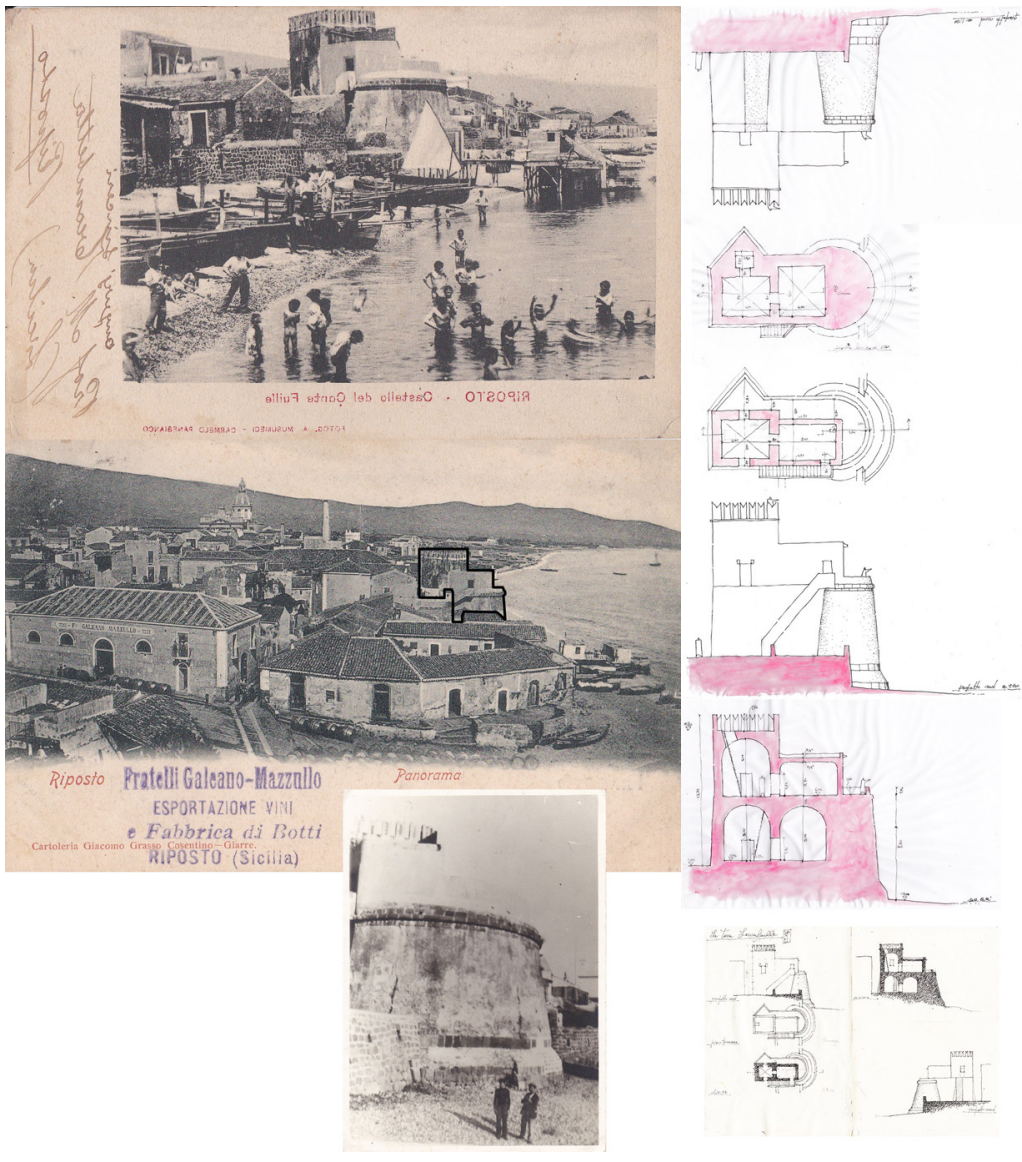


\section{Case studies}

Of the Archirafi tower, we had as references the descriptions, surveys and drawings of the existing and restoration work carried out during surveys between 1578 and 1584 by Tiburzio Spannocchi, Giovan Battista Fieschi Garaventa and Camillo Camiliani (fig. 2). The historian Cristaldi transcribes the extract from the report made by Fieschi as follows, making the necessary conversions from palms and canes to the metric system: 'The Tower of Archirafi appears as a two-floor structure with a circular plan, about 14 metres high, about 8.5 metres wide and flanked by a small courtyard, inside which there is a fresh water well' [Cristaldi 2018, p. 31 ] . At the time of the event, the tower was in a precarious state of preservation, due to the erosive action of atmospheric events in this area, which led to its slow and definitive disappearance around the middle of the 19th century. In the Descrttione dell'isola di Sicilia [Scarlata 1993, p. 539] Camillo Camilliani, in addition to a careful graphic representation of the tower, in which he confirms the circular layout and the presence of the perimeter ravelin, proposes a project for its maintenance and safety. Its geometry and shape is also confirmed by Tiburzio Spannocchi in his survey carried out earlier in I578, with a detailed description of the territory in which the Archirafi tower stood, the distances and connections with the other surrounding fortresses and the predominant function of control and defence of the Contea di Mascali. The tower was related to the south with the promontory where the Tower of Sant'Anna di Capo Mulini was located in the territory of Acireale and to the north with the fortress of Castelmola, as well as having a wide visibility with the Calabrian coast and the Strait of Messina. The analogue graphic reconstruction (preliminary sketches, plan, elevations and sections) (fig. 3) and the3D model of the tower, and thus the virtual and dynamic rendering of the tower by means of photoinsertion (fig. 4), were elaborated from the examination of the illustrated documentation.

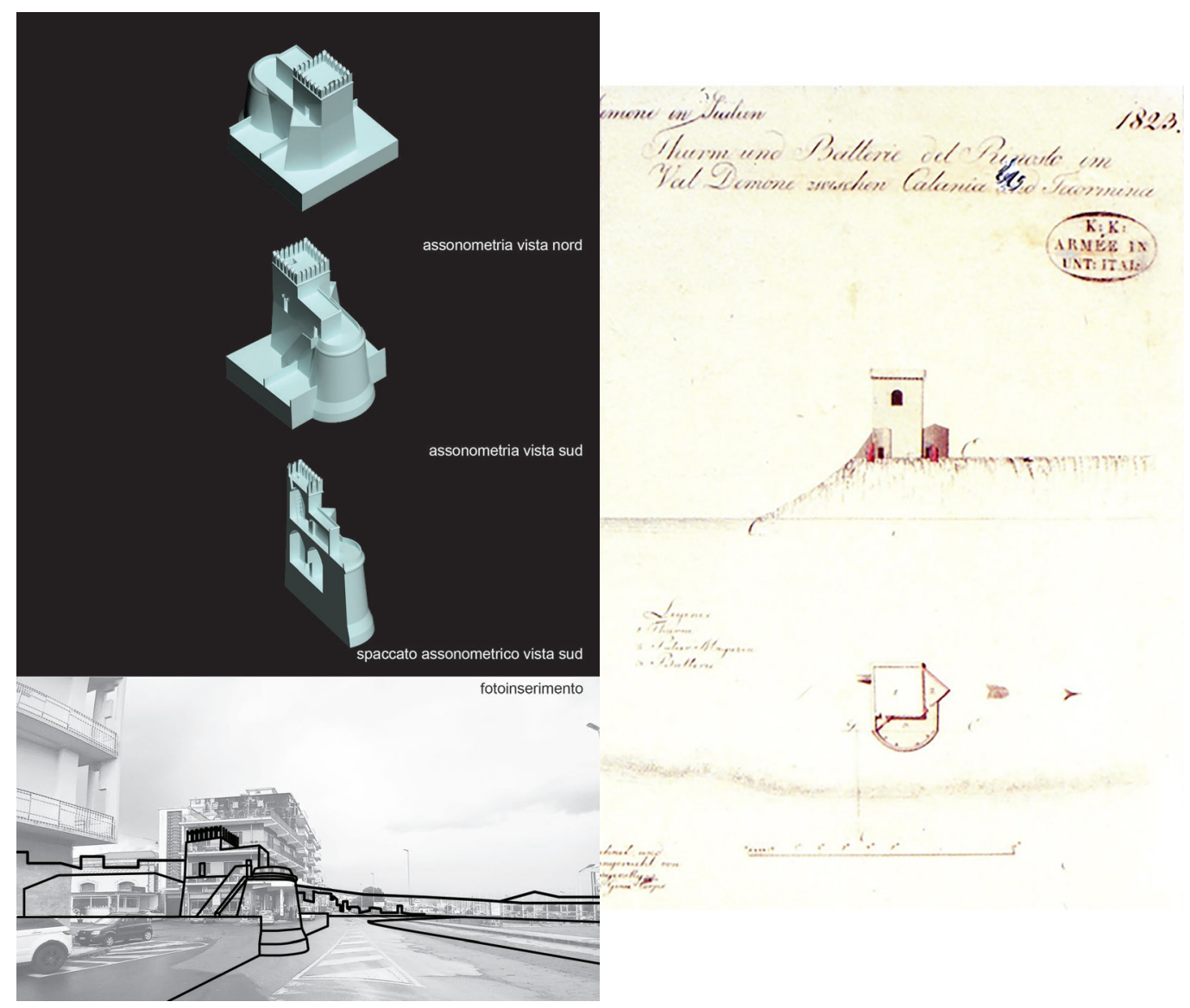


The direct study of the proportions dictated by the pure geometry of the tower, the analysis of the stylistic and typological corollary compared with other towers of the same period, has returned a design controlled by measurement, obtaining a sort of "inverted" survey. It also made it possible to develop a re-semanticisation of the visible artefact and its design inserted in a context which today is different from how it must have appeared in the past. The Laviefuille tower is a different matter, perhaps built to replace the ruined Archirafi tower. Its construction in fact dates back to 1752 "when a new defensive structure was built, according to the will of the viceroy Eustachio Laviefuille, for the protection of the loader of Riposto" [Cristaldi 20 I8, p. 55]. The tower was "inconsolably' [Correnti 1985, p. I 66] demolished by the mayor of the seaside village in 1925. In the absence of satisfactory documentation, the examination took place through a photographic (20th century) and cartographic (fig. 5) repertory that allowed the analogical graphic reconstruction, preliminary sketches and orthogonal restitution of plans, elevations and sections (fig. 6). This was followed by the construction of the three-dimensional model with a further dimensional and geometric comparison of the urban fabric by means of photo-insertion (fig. 7).

The fort had an advanced circular truncated cone-shaped bastion with a summit stringcourse and lava stone base. It incorporated a quadrangular tower tapering to the upper room. In the absence of a photographic repertory, the north-facing façade was taken from a survey of I 823 (fig. 8) [Russo 1994, p. 536]. The result is a hypothesis of reconstruction to complete the fortress, with the quadrangular tower incorporated by the reinforcement of the tapering, which advanced to the north as a salient and terraced bastion. It was connected by a walkway to the parade ground of the circular bastion facing the sea. It is assumed that the interior was divided into two levels, a first level inside the bastion with two vaulted rooms connected by a wooden staircase to the upper room, connected by a trapdoor to the crenellated terrace. A superstructure built later overlaps the parade ground of the circular bastion. The fort must have been embedded in the height of the embankment of the fishing village, higher than the sea level. Hence the hypothesis that the circular bastion was built as a containment and reinforcement for the pre-existing quadrangular keep.

Fig. 9. Claudio Patanè, Drawing of the 'room' (camera chiara), 2021. Analogue narrative/ information platform, located at the water's level, in the context where the Archirafi Tower once was located The historic Palazzo Vigo host the digita "room" host the digital "room" (camera oscura), for immerity. reality. Watercolour and ink on carnet de voyage.

Fig. I 0. Claudio Patanè, Drawing of the 'room (camera oscura), 202 Analogue and digital narrative/informative space, located in the context of the former Laviefuille TowerThe construction of the pavilion will also allow pavilion will also allow redefined and redeline and ink on carnet de voyage.

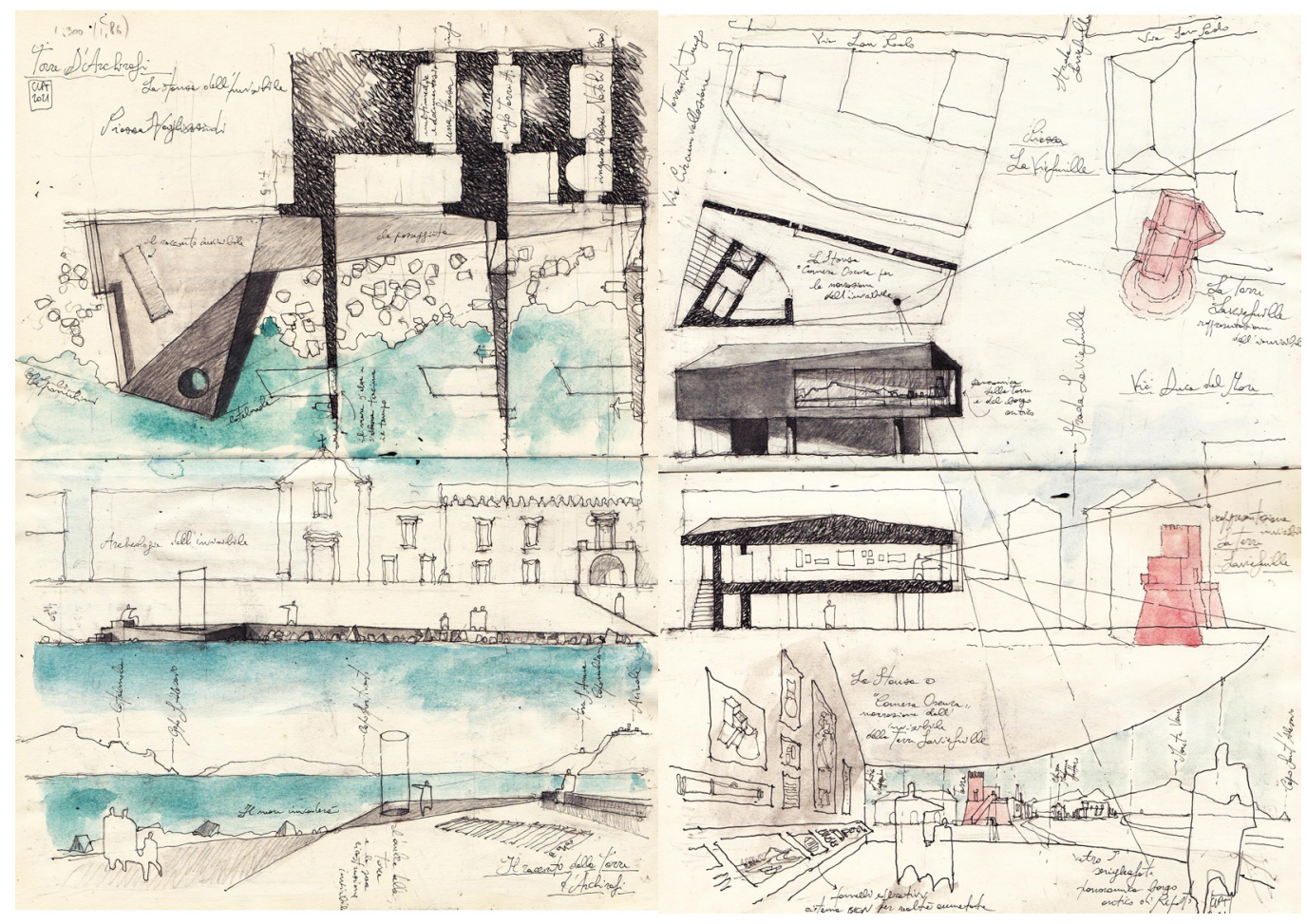




\section{Conclusions}

The work of restitution and reconstruction of the two artefacts, carried out in 'mixed' mode [Patanè 2020, pp. I 57- | 65], analogue and digital; the comparison of the drawings made using classic techniques of direct representation and the construction of a virtual model, led to the need to design a widespread museum itinerary connecting the two 'invisible architectures'. The beginning and completion of the itinerary will be marked by the presence of two 'narrative rooms', or pavilions, that tell the story and their connection with a wider territorial system, referring to that of the ancient defence of the Contea di Mascali, its landscape and its hinterland. The 'rooms' will be constructed spaces that will redevelop the urban context in which the Archirafi and Laviefuille towers were located. The 'room' will be a spatial device, crossable by the inhabitants/visitors who will make it an interactive experiential moment between reality and virtuality. "It is not a question of restoring identically what has been demolished, but of appealing to the memory of the inhabitants through a series of references, giving the historic centre a new dimension. This practice allows architects to link the existing to the past but also to highlight new and specific elements of the same places that guarantee their identity" [Burkhardt 1999, p. 34].

In the case of the Archirafi tower, an open-air 'camera chiara' will act as a platform, between sky and sea, on the terracqueous landscape, at the water's level, recalling the presence of the fort as the construction of an archaeological deposit that has re-emerged on the surface through the traces of the past (fig. 9). "The proposed move is to give depth to the ground" [Viganò 1999, p. 181] at the limit of the horizon of the sea, where the overflowing of the waves gives new meanings of absence, disappearance and oblivion. The drawing constructs this desire to connect with the invisible through symbols and geometries. The empty cylin-

Fig. I I. Example image of digital devices for immersive and virtual iteration of the Archirafi Tower. (graphic elaboration by Claudio Patanè and Dario Calderone).

Fig. 12. Exploded map of the "Itinerary of the Invisible'. Connections of the latent heritage of the latent heritage
of the ancient Contea of the ancient Contea di Mascali. The diagram represents an unusual conceptual map, constructed from the intermittent connections between the two towers of Archirafi and Laviefuille with the remaining defensive system of the territory of the Contea di Mascali. Interacting, moreover, with those visible or invisible traces of landscape, anthropic, archaeological and urban character.
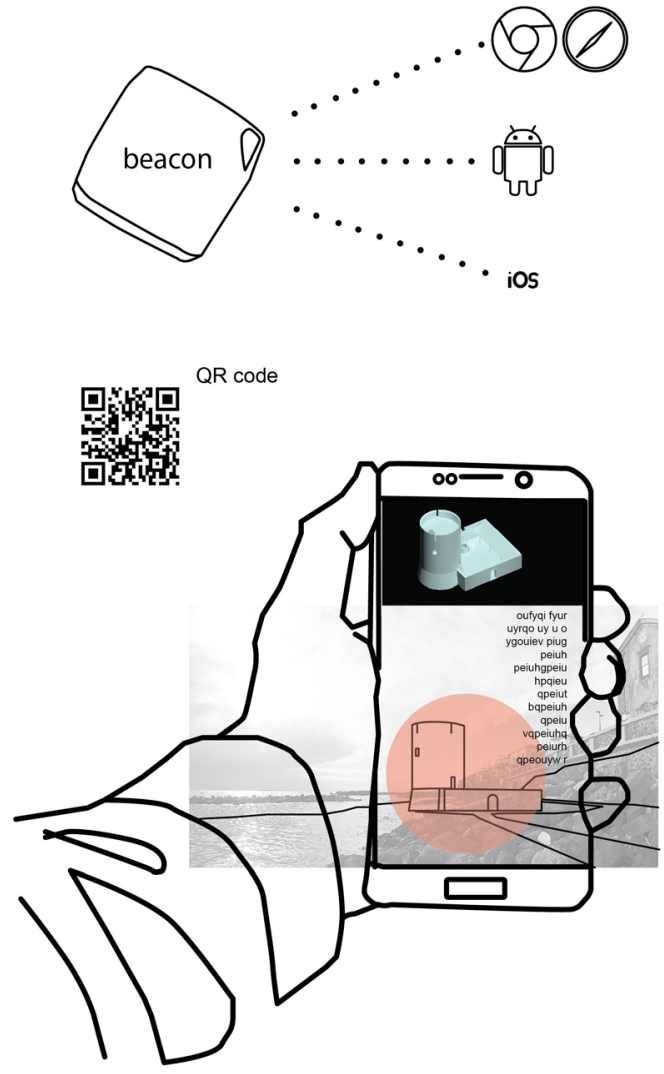

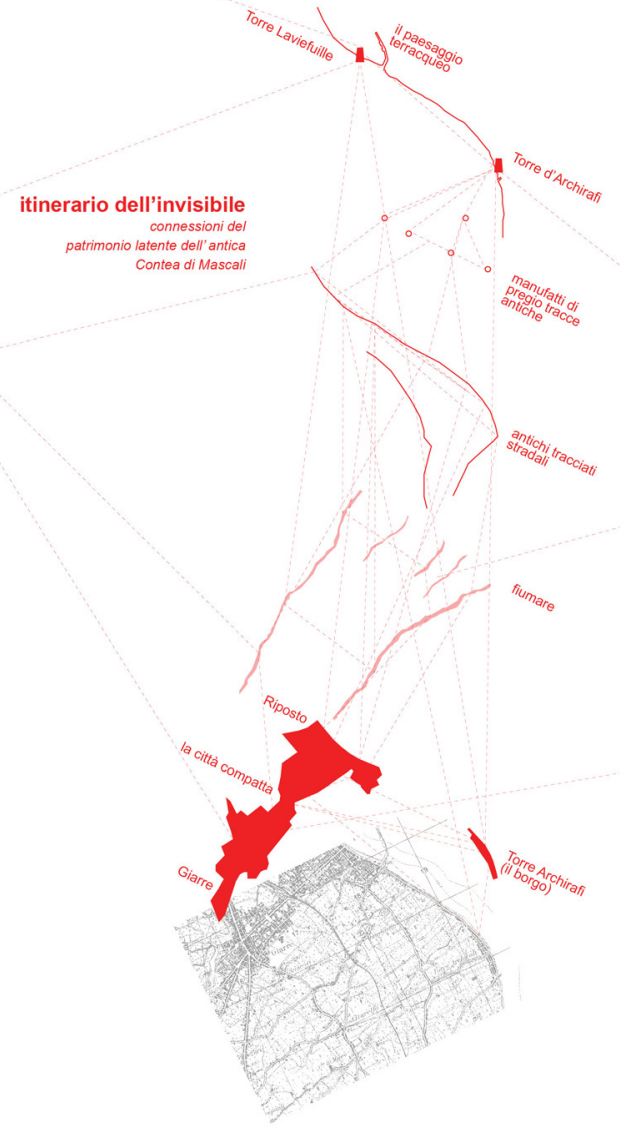


der of the tower, excavated by the water of the sea, perforated and inclined on the platform that will be directed towards Castelmola and Torre Sant'Anna di Capo Mulini. Narrations engraved on the floor and seated, to con-template and build a horizon made of sky and sea. A multimedia 'camera oscura' inside the historic Palazzo Vigo will allow for informed interaction with the historical documentation and virtual representation of the tower's past. The context of the Laviefuille tower is full of contradictions and excesses of a building and infrastructural nature for the sea front of the town of Riposto. Only imperceptible traces remain in the perimeter of the blocks, but the morphological and orographical characteristics of adherence, landing and facing the sea have changed.The cross-section of the roadbed has sloped, increasing the load on vehicles. The current tourist port has definitively removed "the gaze of the sea [...] 'personification' of the equorea extension" [Purpura 20 I0, p. 13], which used to look at the inhabitant, now distracted and disinterested. The "narrative room" of the Laviefuille tower looks like a 'camera oscura', whose space will catalyse the image of the ancient fishing village, its tower and the Contea di Mascali and project it from within. A panoramic projection on screen-printed glass will represent the ancient city and its fortress. The inhabitant/visitor will interact with immersive reality devices and direct contact devices to consult, touch, imagine, invent what has disappeared. The construction of the 'narrative room' will stand suspended over an urban void, binding and stitching together the fabric of the city, now devoid of architectural and urban quality. The construction of this suspended space will follow the now invisible traces of the ancient mouth of the Torrente Jungo, today Via Circumvallazione-Largo Carmine and the longitudinal layout of today's Via Duca del Mare (fig. I0).

Finally, by combining the use of 3D models and the information embedded in GIS platforms, it will be possible to create those processes of heritage valorisation and promotion that are also based on augmented reality [Solima 2019, pp. 177-2I5], a technology that is gaining increasing appreciation among those working in the cultural sector, as well as its target audience. The elaboration of cultural applications based on the use of augmented reality [Bonacini 20 I4, pp.89-I I I] (fig. I I), will make the digitisation of the architectural and archaeological heritage of the ancient Contea, a very important resource also for its territory protagonist of our research, in order to protect the memory of places and contexts that although no longer physically existing, can still transmit culture and knowledge through the new and innovative forms of fruition (fig. 12). "To relate a punctual system of artefacts, existing and not, constituted by the watchtowers, to make them 'keys' of a system of places of culture and widespread character, which 'sight and welcome' in tangible, palpable form, that horizon made of sea or land, of history, memory and knowledge" [Fatta 2019, p. 902].

\section{Acknoledgements}

The authors would like to thank Maria Coppolino, Davide Cristaldi, Salvatore D'Urso, Gaetano Cannavò and Vera Pennisi for their support in this research.

\section{Notes}

[I] The digital restitution of lost buildings is also fundamental in this respect in order to initiate in-depth analyses of the architecture of the monuments with a view to identifying any architectural components relating to periods prior to the 16 th century.

[2] The use of GIS applications in order to reconstruct the logic with which a certain territory was managed and occupied in antiquity has developed a well-defined methodological approach in the field of archaeology. For further examples, which well describe the possibilities offered by this approach see: [Gioia 20 16, pp. I37- I48]; [Calderone 2020, pp. 75-88]; [Pizziolo 2017, pp. 381-387].

\section{References}

Bonacini E. (20|4). La realtà aumentata e le app culturali in Italia: storie da un matrimonio in mobilità. In II capitale culturale Studies on the Value of Cultural Heritage. vol. 9, pp. 89- I I I.

Buzzati D. (1998). Il deserto dei Tartari. Milano: Mondadori. [Prima ed. II deserto dei Tartari. Milano I940]. 
Burkhardt F. (1999). Ricostruzione della Chiesa Madre e ridisegno di piazza Alicia e delle strade adiacenti, Salemi, Trapani. In Domus. n.813, pp.34-42.

Calderone D. (2020). Rotte e vie di comunicazione attraverso i monti Sicani durante il Neolitico: Ipotesi di viabilità di lunga durata tra Campofranco e Milena (CL). In Ipotesi di Preistoria. vol. I3, 2020, pp. 75-88.

Correnti S. (1985). RIPOSTO nella storia, nell'arte e nella vita del suo popolo. Catania:Tringale Editore.

Cristaldi D. (20 18). La Torre di Archirafı e le difese della Contea di Mascali. Acireale-Roma: Gruppo Editoriale Bonanno.

Del Giudice D., Scolari M. (2007). Un numeroso mondo. In Marzari G. (a cura di) Massimo Scolari. Milano: Skira.

Fatta F., Maraffa A., Patanè C., (2020). Geometrie dello sguardo nel paesaggio calabrese. In Palazón J.N., García-Pulido L.J. (eds). FORTMED 2020, Defensive Architecture of Mediterranean. Atti del convegno Granada (ESP), vol. Xl, pp. 899-906.

Gioia D., et al. (2016). A Geoarchaeological study of the Metaponto coastal belt, souther Italy, based on geomorphological mapping and GISsupported classification of landforms. In Geogr. Fis. Dinam. Quat. n. 39, pp. I 37 - I 48.

lachello E. ( I991). II vino e il mare. "Trafficanti” siciliani tra "700 e '800 nella Contea di Mascali. Catania: Maimone Editore.

Patanè C., et al. (2020). Farsi di/segno La Calzada de Béjar narrazione grafica di un borgo. In Agustín-Hernández L., Vallespín Muniesa A., Fernández-Morales A. (eds.). EGA Saragoza 2020. Atti del XVIII convegno. Springer, vol. III, pp. I57-I 65.

Pizziolo G. et al. (2017). II paesaggio archeologico del Gargano. In Radina F. (a cura di). Studi di Preistoria e Protostoria - 4 Preistoria e Protostoria della Puglia, tra Neolitico antico ed Eneolitico finale. Firenze: Istituto Italiano di Preistoria e Protostoria, pp. $38 \mid-387$.

Purpura M. A. (20 I0). Lo sguardo del mare. Scrittori al confino e rappresentazione letteraria dell'immagine marina nel Novecento. Palermo: Gruppo Editoriale Kalós.

Russo F. ( 1994). La difesa costiera del Regno di Sicilia dal XVI al XIX secolo. Tomo I e II. Roma: Ufficio Storico Stato Maggiore Esercito.

Scarlata M. (1993). L'opera di Camillo Camilliani. Roma: Ist. Poligre Zecca dello Stato.

Solima L. (2019). Management per l'impresa culturale. Roma: Carocci ed.

Viganò P. (1999). La città elementare. Ginevra-Milano: Skira

Authors
Claudio Patanè, Università Mediterranea di Reggio Calabria, claudio.patane@unirc.it

Dario Calderone, Università degli studi di Catania, dario.calderone@phd.unict.it

To cite this chapter. Patanè Claudio, Calderone Dario (2021). L'invisibile rivelato. Disamina e progetto per un itinerario museale diffuso dell'antica Contea di Mascali/The invisible revealed. Analysis and plan for a widespread museum itinerary of the Ancient County of Mascali. In Arena A. Arena M., Mediati D., Raffa P. (a cura di). Connettere. Un disegno per annodare e tessere. Linguaggi Distanze Tecnologie. Atti del $42^{\circ}$ Convegno Internazionale dei Docenti delle Discipline della Rappresentazione/Connecting. Drawing for weaving relationship. Languages Distances Technologies. Proceedings of the $42^{\text {th }}$ International Conference of Representation Disciplines Teachers. Milano: FrancoAngeli, pp. 1796-1813. 